\title{
Matching Level And Investors' Heterogeneous Beliefs
}

\author{
Hyunuk Jung, Dong-A University, South Korea
}

Sanghyuk Moon, Yeungnam University, South Korea

\begin{abstract}
This study investigated the relation between matching level and investors' heterogeneous beliefs using listed firm (KOSPI) data in Korea. This study is based on prior research that reported that the higher the matching level, the less the noise included in accounting earnings and the higher the earnings quality. Karpoff (1986), Bamber (1987), Ajinkya, Atiase, \& Gift (1991) and Dormeier (2011) explain that if there are different interpretations among investors regarding intrinsic value of a company, as a result, the trading volume can represent investors' heterogeneous beliefs.

Whereas the previous studies on matching level analyzed what kind of impact matching level improvement has on earnings quality, accumulated market adjusted return, foreign ownership, future earnings response coefficient (FERC) and bond credit rating. However, these studies have problems in measuring the matching level. So this study suggested additional proxy on matching level in addition to the proxy used in previous studies. Specifically, we analyzed the matching level model of Paek's (2011b) by using the Prais-Winsten estimation method and then used the calculated explanatory power $\left(A d j . R^{2}\right)$ as a proxy for the additional matching level.

To empirically analyze hypothesis of this study, we used firm-year observation from 4,094 firms listed on Korean Stock Exchange over the period from 2003 to 2011. We found that matching level regression coefficient consistently showed significantly negative values for each measurement. Moreover, we analyzed additionally by measuring the calculated regression coefficient $\left(\beta_{2}\right)$ of current expenses as matching level response coefficient after analyzing Dichev and Tang's (2008) matching level measuring model by Prais-Winsten estimation method. It showed that regression coefficient of the current expenses and trading volume have negative correlation. This is consistent with this study, and it can be analyzed that as matching level improves, investors' heterogeneous beliefs decrease.

According to microeconomics theory of Mas-Colell, Whinston, and Green (1995), trading volume is explained to affect price changes. However, accounting and related studies analyze the information effect by using price change only. In this sense, this study is meaningful in that it conducted an analysis on the information effect of matching level through trading volume. In addition, this study contributes to understand the microscopic structure of the capital market.
\end{abstract}

Keywords: Earnings Quality; Matching Level; Trading Volume

\section{INTRODUCTION}

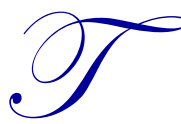
he purpose of this study is to analyze the hypothesis that there is a negative relationship between matching level and investors' heterogeneous beliefs. Based on that the assumption that matching level reduces the noise included in earnings, we determined if investors' heterogeneous beliefs decrease as matching level increases.

Karpoff (1986), Bamber (1987), Ajinkya et al. (1991) and Dormeier (2011) explain that if there are different interpretations among investors regarding intrinsic value of a company, the trading volume can represent investors' heterogeneous beliefs. Studies of trading volume report that when investors' beliefs regarding intrinsic value of the firm are heterogeneous, it has positive relation with unexpected earnings, but a negative relation with the quality of accounting information (e.g., accruals quality) of asymmetric information (e.g., analysts' earnings forecasts) and 
information environment such as company size and age (Karpoff, 1986; Bamber, 1987; Ajinkya et al., 1991; Jung, 1990; Choi \& Shin, 1997; Choi \& Yoon, 2012).

Whereas the previous studies on matching level analyzed what kind of impact matching level improvement has on the earnings quality, accumulated market adjusted return, foreign ownership, future earnings response coefficient (FERC) and bond credit rating (Roh, 2013; Lee, Goh, \& Choi, 2013; Lee \& Jung, 2014; Lee, 2014; Jung \& Lee, 2014). Previous studies of matching level use the methodology suggested by Paek (2011).

Paek (2011b) measures matching level of each firm with calculated explanatory power (Adj. $\mathrm{R}^{2}$ ) after analyzing relation between current income and current expenses by ordinary least squares by using the data of each company's rolling ten-year windows. However, the model used by Paek (2011a) disregards the first auto correlation relationship that can occur econometrically. Therefore, Lee and Jung (2014) and Jung and Lee (2014) measure matching level by changing the measure used by Paek (2011b) to the form of difference $(\triangle)$ type.

The model that Lee and Jung (2014) and Jung and Lee (2014) suggests was designed to solve the first autocorrelation problem that can arise in Paek's (2011b) model, but if the time lag is set long-term, the difference amount can disappear to zero value. So we analyze the matching level model of Paek (2011b) by using the PraisWinsten estimation method and then use the calculated explanatory power (Adj. $\mathrm{R}^{2}$ ) as a proxy for the additional matching level.

Investors' heterogeneous beliefs were measured by trading volume, and trading volume was measured based on the methodology suggested by Morse (1981), Beaver (1968), Bamber (1987) and Ziebart (1990). By setting the trading volume as the dependent variable, after considering the effect of the control variable that the previous studies suggest in regression analysis that includes matching level as independent variable, matching level's regression coefficient consistently showed significantly negative value for each measured value. Moreover, after analyzing Dichev and Tang (2008) matching level measuring model by Prais-Winsten estimation method, we analyzed the effect of matching level on investors' heterogeneous beliefs by using calculated current expense repression coefficient $\left(\beta_{2}\right)$ According to the additional analysis, as the value of regression coefficient of current expense increases, trading volume decreases. In other words, as matching level improves investors' heterogeneous beliefs decrease for the target investment company.

According to microeconomics theory, trading volume affects price change (Mas-Colell et al., 1995). However, the impact of the information was analyzed by using only the price change in studies of accounting. We conducted an empirical analysis on the effect of information on matching level by trading volume. This study is expected to help us understand the capital market's microscopic structure.

The rest of this paper is organized as follows. Section II reviews the literature and presents the hypothesis. In Section III, we describe our methodology. We present descriptive statistics and the results of the empirical test in Section IV. Section V concludes with implications and limitations of the analysis.

\section{LITERATURE REVIEW AND HYPOTHESIS DEVELOPMENT}

\subsection{Literature Review}

Dichev and Tang (2008) explain that if contemporaneous correlation between current income and current expenses, in other words, matching level, is damaged, noise that included in the earnings increases. Paek (2011b) explains that if noise that is included in the earnings increases, earnings quality diminishes. Therefore, Paek (2011b) reports result that groups with high matching level have high earnings quality (e.g., earnings persistence, earnings predictability, accruals quality, income smoothing, and earnings response coefficient). Dichev and Tang (2008) that investigated on the US (1,000 largest U.S. firms) also reported consistent results, and Dichev and Tang (2008) reported that as matching level increases, earnings persistence increases but earnings volatility decreases.

In this context, studies on matching level have analyzed the relationship between company characteristic variable and matching level in Korea (Roh, 2013; Lee et al., 2013; Lee \& Jung, 2014; Lee, 2014; Jung \& Lee, 2014). 
Previous studies of matching level analyzed the relationship of matching level with Foreign Ownership, analysts' herding, asymmetric information (analyst's forecasts), audit hours, the information effect of current earnings and future earnings, and bond credit rating.

Chon (2003) explained that foreign investors make investment decisions for companies with high earnings quality. Lee (2014) conducted an analysis with the expectation that companies with a higher matching level would have higher foreign ownership. According to the analysis, there is a positive correlation between matching level and foreign ownership. Lee (2014) interpreted that as matching level increases, earnings quality improves and thus foreign ownership increases.

Bhattacharya, Ecker, Olsson, and Schipper (2012) report that if the earnings quality increases, information risk (asymmetric information level) is decreased. It shows as matching level rises, uncertainty of information environment and asymmetric information level can fall.

Kwon and Ki (2011) reports that the higher accrual quality, the higher audit risk, so auditors will spend more time auditing than when audited companies have a low (high) quality of accruals. Accrual quality, which is one of the audit risk criteria will increase as matching level improves (Paek, 2011b). In other words, as client's matching level increases, less time is spent on auditing. Therefore, Jung and Lee (2014) reported results where there is negative relationship between matching level and audit hour.

According to Tucker and Zarowin (2006) and Haw, Hu, and Lee (2012), higher the earnings quality (income smoothing, accruals quality) higher the share price relation with future earnings. Lee and Jung (2014) expected a positive relationship between matching level and future earning's relation to share price. According to analysis results, as matching level increases, so does the future profit's relation to share price. Lee and Jung (2014) interpreted that as matching level improves, the information effect of future earnings increases.

In contrast, Roh and Lee (2012) studied the information effect of matching level through accumulated market adjusted return. According to the results of the analysis, information effect of earnings is higher in the group with a high matching level than in groups with a low matching level. With these results as a basis, they explained that matching level improves earnings predictability by reducing noise that is included in earnings.

Yang and Seo (2014) analyzed the impact of matching level on assessment of bond credit rating. According to the analysis result, as matching level increases, so does the bond credit rating. According to Ashbaugh-Skaife, Collins, and LaFond (2006), as earnings quality (accrual quality and income smoothing) increases, bond credit rating goes up. The results of Yang and Seo (2014) are consistent with those of Ashbaugh-Skaife et al. (2006).

The previous studies of matching level show that as matching level increases, noise that is included in earning decreases and the uncertainty of earning and the earnings. Therefore, previous studies of matching level report that as matching level improves, asymmetric information level and audit hour decreases, and foreign ownership, in formation effect of earning (future earning) and bond credit rating increase.

\subsection{Hypothesis Development}

According to the literature, heterogeneous (or differing) beliefs and trading volume have a positive relation (Karpoff, 1986; Bamber, 1987; Ajinkya et al., 1991; Dormeier, 2011). These studies explain that because trading volume increases when there are heterogeneous beliefs in intrinsic value of a company, trading volume can signify heterogeneous beliefs among investors (Karpoff, 1986; Bamber, 1987; Ajinkya et al., 1991; Jung, 1990; Choi \& Shin, 1997; Choi \& Yoon, 2012). Therefore, studies of trading volume analyzed how much impact unexpected earnings, quality of accounting information (accruals quality), level of asymmetric information (analyst's forecasts) and information environment (firm size, firm age) have on investors' heterogeneous beliefs.

Bamber (1987) reported that the magnitude of the trading volume to quarterly earnings announcement is positively related with the unexpected. Choi and Shin's (1997) study of on Korean companies showed consistent results. Jung (1990) explained that new information causes various interpretations regarding expected (future) cash follow for 
investors. The information that is included in the unexpected earnings seems to generate several interpretations regarding future cash flow for investors.

However, Sohn, Ko, and Paik (2009) reported that if accruals quality is high, the positive relationship between unexpected earnings and trading volume decreases. In other words, if companies provide good quality accounting information, investors' heterogeneous beliefs regarding unexpected earnings can be mitigated.

Ajinkya et al. (1991) analyzed the relation between dispersion of analysts' forecasts and trading volume. They found a positive relation between profit forecast dispersion and trading volume. Ziebart (1990) analyzed the relation between financial analysts' forecasts dispersion change and analysts' forecasts adjustments and abnormal trading volume. According to the result, there is a positive relation between analysts' forecasts dispersion change and analysts' forecasts and abnormal trading volume. Similarly, Choi and Shin (1997) analyzed relation between analysts' forecasts dispersion for Korean companies and trading volume. They found that as analysts' forecasts dispersion increases, so did trading volume.

Jung (1990) analyzed relation between information environment and trading volume. Specifically, Jung (1990) has conducted an analysis on how information environment measured value impacts trading volume by measuring information environment with firm size and age. According to the analyzed results, as firm size is bigger and firm age is higher, trading volume is shown to decrease. Analysis result, as asymmetric information level is low and company information environment is outstanding, investors' heterogeneous beliefs about target investment companies are to be decreased

As we summarize the literature on trading volume, when there are investors' heterogeneous beliefs on intrinsic value of a company, trading volume increases. Investors' heterogeneous beliefs increase when earnings quality is low, and asymmetric information level (information environment) is high (low).

Dichev and Tang (2008), Paek (2011b), Roh and Lee (2012) and Lee (2014) argued that as matching level increases, noise that is included in accounting earning decreases. Dichev and Tang (2008), Paek (2011b) and Roh and Lee (2012) reported that as matching level improves, uncertainty in accounting earning decreases and earnings quality consequently increases. If matching level acts as a factor to improve the earnings quality, it is expected that as matching level increases, investors' heterogeneous beliefs on intrinsic value of a company will decrease. Therefore this study hypothesizes a negative association between matching level and investors' heterogeneous beliefs.

Hypothesis: Ceteris paribus, as matching level increases, investors' heterogeneous beliefs will decrease.

\section{RESEARCH DESIGN}

\subsection{Methodology and Variable Definitions}

\subsubsection{Model for Matching Level and Investors' Heterogeneous Beliefs}

We used the following equation to analyze the effect of matching level on investors' heterogeneous beliefs.

$$
\begin{aligned}
& T V(A T V)_{i, t}=\beta_{0}+\beta_{1} P E X P 2_{i, t}+\beta_{2} V D_{i, t}+\beta_{3} \operatorname{SIZE}_{i, t}+\beta_{4} B I G_{i, t}+\beta_{5} L E V_{i, t}+\beta_{6} B O D_{i, t} \\
& +\beta_{7} U E_{i, t}+\beta_{8} C F_{i, t}+\beta_{9} A G E_{i, t}+\beta_{10} Y D_{i, t}+\beta_{11} I C O D E_{i, t}+\varepsilon_{i, t}
\end{aligned}
$$

TV : Daily average trade volume

ATV : Daily abnormal trade volume

MAT : Matching level measured based on Paek (2011b)

GMAT : Matching level measured based on Lee and Jung (2014)

DMAT : Matching level measured based on Jung and Lee (2014)

PMAT : Matching level measured based on Prais-Winsten methods

VD : Voluntary disclosures (Voluntary disclosure level/ln((t-1) total assets))

SIZE : $\ln$ (total assets at the end of year) 


$\begin{array}{lll}\text { BIG } & : & 1 \text { if the auditor is big } 4, \text { or } 0 \\ \text { LEV } & : & \text { Total liability/total assets at the end of year } \\ \text { BOD } & : & \text { Percentage of abnormal outside directors } \\ \text { UE } & : & \text { Unexpected earnings measured based on Han (2001) } \\ \text { CFS } & : & 1 \text { if consolidated financial statements are announced, or } 0 \\ \text { AGE } & : & \text { ln (the consecutive number of months listed on KOSPI) } \\ \text { YD } & : \text { Dummy variable for year. } \\ \text { ICODE } & : \text { Dummy variable for industry. } \\ \varepsilon & : \text { Residuals }\end{array}$

Equation (1) $\beta_{1}$ is a verification coefficient for the hypothesis, and for $\beta_{1}$ to show consistent results with the hypothesis, it needs to show significant negative value. If $\beta_{1}$ shows significant negative value, it can be explained that as matching level increases, investors' heterogeneous beliefs decrease.

Diamond and Verrecchia (1991) reported that higher the disclosure level, the higher the liquidity of the shares. This suggests that as the amount of information provided by a company increases, so does trading volume. Therefore, we have included voluntary disclosure degree (VD) in the model to control the effect of voluntary disclosure level on trading volume. The level of voluntary disclosure was collected from the Data Analysis, Retrieval and Transfer System provided by the Korean Financial Supervisory Service. Firm size is included in the model to control the effect the firm size on the trading volume. Bhushan (1989) reported that as firm size increases, analyst following increases. It means that as firm size increases, asymmetric information can be low. Therefore, this study includes firm size (SIZE) in the model. We expect the regression coefficient of SIZE to be negative. Becker, DeFond, Jiambalvo, and Subramanyam (1998) reported that big six auditors provide higher audit quality services to clients than do non-big six auditors. Therefore, we have included the auditor size (Big) in the model to control the effect the quality of audit has on trading volume. Size is expected to have a negative association with trading volume. Debt ratio is a variable representing firm's financial risk and bankruptcy risk, we have included debt ratio (LEV) in the model to control the effect of these risks on trading volume. The regression coefficient of LEV is expected to have a positive value. We have included excess outside director rate (BOD) in the model to control the ownership structure. Kim and Kim (2007) reported that higher the outside director ratio, the more likely it is that the agent problem has been resolved, and Ko, Baik, and Ahn (2012) explained that companies with high outside director ratio will likely to have a more independent board of directors. However, Kim (2006) showed analysis results where excess outside director rate has no association with firm value. So, this study has included excess outside director rate(BOD) in the model to control the ownership structure, but a relationship is not expected.

Bamber (1987) reported a positive relation between unexpected earnings and trading volume. According to Han (2001), unexpected earnings include the most information among the financial variables. For that reason, information included in unexpected earnings can trigger a variety of interpretations regarding future cash follow for investors, thus this study has included unexpected earning s(UE) in the model. Hwang (1995) explained that consolidated financial statement can provide additional information that each financial statement cannot provide. Therefore, in this study, we have included consolidated financial statement announcement (CFS) in the model. If consolidated financial statements provide additional information that each financial statement cannot provide, consolidated financial statements are expected to have positive relation with trading volume. Jung (1990) explained that firm age can show information environment. Jung (1990) reported that because higher the firm age, company information environment can be outstanding, thus there is negative relation between firm age and trading volume. However, Kwon and Moon (2012) explained as companies enter the decline phase in their life cycle, their opportunistic earnings management risk increases. In this case, firm age has a positive relation with trading volume. Therefore, this study has included firm age (AGE), but no relationship is expected. Lastly, year dummy and industry dummy are included in the model to control the year effect and industry dummy.

\subsubsection{Measuring of Investors' Heterogeneous Beliefs}

This study has measured investors' heterogeneous beliefs by trading volume. Trading volume used in this study was measured as equation (2) and equation (3). 
Equation (2) and equation (3) are based on the methodology of Morse (1981), Beaver (1968), Bamber (1987) and Ziebart (1990). However, previous studies measured the trading volume with a limited window period (earning announcement date). Kim and Verrecchia (1994) explained that accounting earning announcement time has higher asymmetric information level than non-accounting earning announcement time. Therefore, this study measured the trading volume by using the law of large numbers.

Firstly, equation (2) is average daily trading volume (TV), and this is stock trading volume for each company for 1 year. Companies with higher investors' heterogeneous beliefs have increased daily average trading volume (TV).

$$
T V_{i N F}=\left[\sum_{t=1}^{n} V_{i t}\right] \frac{1}{T_{N F}}
$$

TV : Average daily volume

$\mathrm{V}_{\mathrm{i}, \mathrm{t}}$ : company's trading date $\mathrm{t}$ days trading volume/ $\mathrm{i}$ company trading days $\mathrm{t}$ days number of listed shares

$\mathrm{T}_{\mathrm{NF}}$ : Trading days in 1 year

However, Equation (2) is limited in showing if daily average trading volume of each company had a positive abnormal or a negative abnormal trading volume. Therefore, this study measured daily abnormal trading volume (ATV). Equation (3) can be explain as if individual company's daily abnormal trading volume (ATV) is bigger than zero, that individual company can be said to have positive abnormal trading volume. Reversely, if individual company daily abnormal trading volume (ATV) is smaller than zero, then that individual company can be said to have negative abnormal share trading volume. In this context, I believe when investors' heterogeneous beliefs regarding intrinsic value of a company increase, daily abnormal trading volume (ATV) will show larger than zero value, but when investors' heterogeneous beliefs are low, daily access trading volume will be smaller than zero.

$$
A T V=\left[\sum_{t=1}^{n} \epsilon_{i t}\right] \frac{1}{T_{N F}}
$$

ATV : Daily abnormal trading volume

$\varepsilon_{\mathrm{i}, \mathrm{t}} \quad: \quad V_{i t}-\left(\hat{\alpha}_{j}+\hat{\beta}_{i} V_{m t}\right)$ (actual trading volume-forecasted trading volume (market model, $\hat{\alpha}_{j}+\hat{\beta}_{i} V_{m t}$ )

$\mathrm{T}_{\mathrm{NF}} \quad$ : Trading days in 1 year

\subsubsection{Measuring of Matching Level (MATCH)}

Paek (2011b) measures matching level through ordinary least squares after setting the current income as dependent variable and current expense as independent variable as in the equation (4). Paek (2011b) measures the calculated Adj. $\mathrm{R}^{2}$ as matching level (MAT) after conducting OLS regression analysis by using each company's current rolling10-year windows data.

$$
R E V_{i, t}=\beta_{0}+\beta_{1} E X P_{i t}+\beta_{2} V D_{i, t}+\varepsilon_{i, t}
$$

RE : (Revenue + non-operating income) / average total asset

EXP : (cost of sales + selling and administrative expense + non-operating expenses) / average total assets

However, the methodology suggested by Paek (2011b) disregards the first autocorrelation relationship that can occur econometrically. Therefore, Lee and Jung (2014) and Jung and Lee (2014) measured matching level in equations (5) and (6) to resolve the first autocorrelation relationship that can appear in Paek (2011b). Specifically, Lee and Jung (2014) measured the calculated Adj. ${ }^{2}$, through OLS regression analysis as matching level(GMAT) after changing equation (4) as the first difference equation as in equation(5). Lee and Jung (2014) conducts OLS regression analysis without using a slope. 


$$
R E V_{i, t}-R E V_{i, t-1}=\beta_{2}\left(E X P_{i, t}-E X P_{i, t-1}\right)+\varepsilon_{i, t}-\varepsilon_{i, t-1} \Delta R E V_{i, t}=\beta_{2} \Delta E X P_{i, t}+v_{i, t}
$$

Please refer to equation (4) for the definitions of the variables.

Whereas Jung and Lee (2014) measured matching level (DMAT) with a difference between 'Adj.R ${ }^{2}$, of equation (6) and 'Adj.R' $\mathrm{R}^{2}$ of equation (7) after conducting OLS regression analysis for equation (6) and equation (7) below. When measuring matching level with these methodology, Jung and Lee (2014) explained that the former and the next term expenses can measure the controlled matching level.

$$
\begin{aligned}
& R E V_{i, t}=\beta_{0}+\beta_{1} E X P_{i, t-1}+\beta_{2} E D P_{i, t}+\beta_{3} E X P_{i, t+1}+\varepsilon_{i, t} \\
& R E V_{i, t}=\beta_{0}+\beta_{1} E D P_{i, t-1}+\beta_{2} E D P_{i, t+1}+\varepsilon_{i, t}
\end{aligned}
$$

Please refer to equation (4) for the definitions of the variables.

The methodology of Lee and Jung (2014) and Jung and Lee (2014) is designed to resolved the first autocorrelation relationship that can appear in Paek (2011b), but when time lag increases, there is a problem that this different type can disappear as zero. In other words, if time is limited as certain period, the difference value does not go to zero, but if the time is set to be infinite, and then this difference value can become zero.

This is also explained consistently in microeconomics theory. In other words, even if a certain market (industry) is currently monopolistic market, if entry barrier called 'time' is resolved, this market (industry) becomes fully competitive. The companies included in the perfect competition market operate in the optimal facility size and are reported to have normal profits only. It means that each company's difference in total revenue and total cost can be zero in the long term.

Moreover, as for the difference type equation as in Lee and Jung (2014) and Jung and Lee (2014), when the sample size is big, small observation loss is not a problem. However, when the sample is small, these observation losses can cause a problem where estimation cannot be the best linear unbiased estimator (Gujarati 2011). So, we measured the matching level by using the Prais-Winsten estimation method.

Prais-Winsten estimation method can be used when there is the first autocorrelation. Specifically, this study used the calculated Adj. $\mathrm{R}^{2}$ as additional matching level measurement (PMAT) through equation (4) with Prais-Winsten estimation method.

Whereas Francis, LaFond, Olsson, and Schipper (2004) explained that rolling 10-year windows for each company is necessary to calculate a firm-specific approach. Therefore, this study used a methodology suggested by Paek (2011b) and consistently each company's rolling ten-year windows data to calculate MAT, GMAT, DMAT and PMAT.

\subsection{Sampling}

The sample used in this study consisted of non-financial firms that traded on Korea Stock Exchange during the sample period 2003 to 2011. In selecting the samples, the following limitations are applied:

(1) Companies that can provide trading volume from 1994 to 2011, financial statement and audit report from KISVALUE (Korea Investors Service Inc) or TS-2000 database (Korea Listed Companies Association)

(2) Companies whose total registered directors and outside directors and the number of voluntary disclosure can be collected from Data Analysis, Retrieval and Transfer System provided by the Korean Financial Supervisory Service

(3) Companies whose financial year ended on December $31^{\text {st }}$ and the audit report showing satisfactory mark and with positive asset level 
The final samples consisted of 4,094 firm-year observations. Table 1 shows the distribution of sample by year. ${ }^{1}$

Table 1. Distribution of sample by year

\begin{tabular}{|c|c|c|c|c|c|c|c|c|c|c|c|}
\hline Year & $\mathbf{2 0 0 3}$ & $\mathbf{2 0 0 4}$ & $\mathbf{2 0 0 5}$ & $\mathbf{2 0 0 6}$ & $\mathbf{2 0 0 7}$ & $\mathbf{2 0 0 8}$ & $\mathbf{2 0 0 9}$ & $\mathbf{2 0 1 0}$ & $\mathbf{2 0 1 1}$ & Total \\
\hline Number & 412 & 427 & 435 & 437 & 445 & 462 & 471 & 493 & 512 & 4,094 \\
\hline
\end{tabular}

\section{EMPIRICAL RESULTS}

\subsection{Descriptive Statistics and Correlation}

Table 2 shows descriptive statistics of variables. Average, median, standard deviation and quartile of each variable were presented. Average (median) of Daily average trading volume (TV) was 0.0112(0.0052) and the standard deviation was 0.0213 . And average(median) of daily abnormal trading volume (ATV) was $-0.0010(-0.0035)$ and the standard deviation was 0.0185 .

In proxies of matching level, average(median) value of MAT was $0.8479(0.9369)$ and it was like the average $(0.881)$ and the median (0.965) of Paek (2011b). Average(median) of GMAT was 0.776(0.8882) and average(median) of DMAT was $0.4680(0.3802)$. This is consistent with the view by Jung and Lee (2014). And average(median) of PMAT was $0.8783(0.9523)$, indicating that the average is somewhat smaller than the median.

In the descriptive statistics for control variables, the average(median) of voluntary announcement degree 0.0492(0.000). In Sohn, Jin, and Hua (2008), the corresponding average and median were 0.031 and 0.000 respectively. So, the results of this study are consistent with the view by Sohn et al., (2008). Firm size (Size) average(median) is 26.4313 (26.1367). Average(median) of auditor size (Big) is $0.6378(1.0000)$, thus it means that about $63 \%$ of the sample companies are audited by big accounting firms. Average(Median) of Debt ratio (Lev) was $0.4428(0.4496)$, thus the average and the median were similar. Average and median of excess outside director rate (BOD) was -0.0018 and 0.0000 respectively, thus it means that more than one half of the sample companies satisfies the legal outside director rate requirement. Average(median) of unexpected earnings was $0.0225(0.0027)$, somewhat smaller than average (0.056) by Han (2011). Average(median) of consolidated financial statement (CFS) was 0.5677 (1.0000), thus about $56 \%$ of the sample companies publicly report consolidated financial reports. Average and median of company age(AGE) were 5.3152 and 5.4467 respectively, thus they are shown to be like the average (5.6002) by Jung (1990).

\footnotetext{
${ }^{1}$ Although not shown in the table, among the final sample of 4,094, there are 413 firms under Manufacture of Chemicals and Chemical Products except Pharmaceuticals, Medicinal Chemicals category, 315 firms under professional services, 311 firms under manufacture of basic metal products, and 217 firms under Manufacture of Electronic Components, Computer, Radio, Television and Communication Equipment and Apparatuses category, thus these 4 industries account for about $32 \%$. Therefore, this study included industry dummy in the model in order to control the industry effect.
} 
Table 2. Descriptive statistics of variables

\begin{tabular}{c|r|r|r|r|r|r|r}
\hline Variables & Mean & $\begin{array}{l}\text { Standard } \\
\text { Deviation }\end{array}$ & Min & $\mathbf{2 5 \%}$ & Median & $\mathbf{7 5 \%}$ & Max \\
\hline TV & 0.0112 & 0.0213 & 0.0000 & 0.0022 & 0.0052 & 0.0118 & 0.5087 \\
\hline ATV & -0.0010 & 0.0185 & -0.1383 & -0.0076 & -0.0035 & 0.0010 & 0.3094 \\
\hline MAT & 0.8479 & 0.2060 & 0.0043 & 0.8109 & 0.9369 & 0.9793 & 1.0000 \\
\hline GMAT & 0.7776 & 0.2565 & 0.0013 & 0.6824 & 0.8882 & 0.9613 & 0.9986 \\
\hline DMAT & 0.4680 & 0.3411 & 0.0011 & 0.1806 & 0.3802 & 0.7131 & 1.2816 \\
\hline PMAT & 0.8783 & 0.1770 & 0.0023 & 0.8573 & 0.9523 & 0.9845 & 1.0000 \\
\hline VD & 0.0492 & 0.1003 & 0.0000 & 0.0000 & 0.0000 & 0.0649 & 1.6822 \\
\hline SIZE & 26.4313 & 1.4804 & 22.9058 & 25.3956 & 26.1367 & 27.2231 & 32.3055 \\
\hline BIG & 0.6378 & 0.4807 & 0.0000 & 0.0000 & 1.0000 & 1.0000 & 1.0000 \\
\hline LEV & 0.4428 & 0.1929 & 0.0007 & 0.2974 & 0.4496 & 0.5847 & 0.9930 \\
\hline BOD & -0.0018 & 0.1182 & -0.5000 & -0.0500 & 0.0000 & 0.0556 & 0.5500 \\
\hline UE & 0.0225 & 0.5221 & -9.8625 & -0.0550 & 0.0027 & 0.0723 & 7.4350 \\
\hline CFS & 0.5677 & 0.4955 & 0.0000 & 0.0000 & 1.0000 & 1.0000 & 1.0000 \\
\hline AGE & 5.3152 & 0.7551 & 0.0000 & 5.0434 & 5.4467 & 5.8992 & 6.5058 \\
\hline
\end{tabular}

The definitions of the variables are as follow: TV= Daily average trade volume; ATV= Daily abnormal trade volume; MAT= Matching level measured based on Paek(2011b); GMAT= Matching level measured based on Lee and Jung(2014); DMAT= Matching level measured based on Jung and Lee (2014); PMAT= Matching level measured based on Prais-Winsten methods; VD= Voluntary disclosures(Voluntary disclosure level $/ \ln ((\mathrm{t}-1)$ total assets)); $\mathrm{SIZE}=\ln ($ total assets at the end of year); $\mathrm{BIG}=1$ if the auditor is big 4, or 0; $\mathrm{LEV}=$ Total liability/total assets at the end of year; BOD: Percentage of abnormal outside directors; UE $=$ Unexpected earnings measured based on Han(2001). CFS $=1$ if consolidated financial statements is announced, or $0 ; \mathrm{AGE}=\ln$ (the consecutive number of months listed on KOSPI)

Table 3 provides the Pearson's correlation between the variables used in empirical analysis. In Table 3, trading volume measured daily average trading volume (TV) and daily abnormal trading volume (ATV) are shown to have significantly negative correlation with MAT, GMAT and PMAT, respectively. DMAT is shown to have significantly negative correlation with ATV, but does not have a significant correlation with TV.

Between trading volume and matching level measurements, all have shown significantly $(\mathrm{p}<1 \%)$ positive correlations. We found a statistically significant positive correlation between the trading volume measurements and voluntary disclosure (VD), debt ration (LEV) and unexpected earnings (UE) at $1 \%$ level $(\mathrm{p}<1 \%)$. But the trading volume measurements have significantly $(\mathrm{p}<1 \%)$ negative correlation with firm size (SIZE), auditor size (Big), excess outside director rate (BOD), and consolidated financial statements (CFS). finally, we found that trading volume measurements and firm age (AGE) do not have a significant correlation. 
Table 3. Pearson's Correlations between Variables

\begin{tabular}{|c|c|c|c|c|c|c|c|}
\hline & TV & ATV & MAT & GMAT & DMAT & PMAT & VD \\
\hline TV & 1.0000 & & & & & & \\
\hline ATV & $0.8492^{* * *}$ & 1.0000 & & & & & \\
\hline MAT & $-0.1257^{* * *}$ & $-0.0996^{* * *}$ & 1.0000 & & & & \\
\hline GMAT & $-0.1567^{* * *}$ & $-0.1436^{* * *}$ & $0.7840^{* * *}$ & 1.0000 & & & \\
\hline DMAT & -0.0230 & $-0.0372^{* *}$ & $0.1395^{* * *}$ & $0.1395^{* * *}$ & 1.0000 & & \\
\hline PMAT & $-0.1210^{* * *}$ & $-0.1056^{* * *}$ & $0.8895^{* * *}$ & $0.8895^{* * *}$ & $0.1498^{* * *}$ & 1.0000 & \\
\hline VD & $0.0465^{* * *}$ & $0.0596^{* * *}$ & $-0.0378^{* *}$ & $-0.0378^{* *}$ & -0.0247 & $-0.0508^{* *}$ & 1.0000 \\
\hline SIZE & $-0.1984^{* * *}$ & $-0.1545^{* * *}$ & $0.0548^{* * *}$ & $0.0548^{* * *}$ & $-0.0419^{* * *}$ & $0.0470^{* * *}$ & $0.2220^{* * *}$ \\
\hline BIG & $-0.1307^{* * *}$ & $-0.1058^{* * *}$ & 0.0213 & 0.0213 & $-0.0269^{*}$ & 0.0187 & 0.0375 \\
\hline LEV & $0.1536^{* * *}$ & $0.1590^{* * *}$ & $-0.0525^{* * *}$ & $-0.0525^{* * *}$ & 0.0198 & -0.0732 & 0.1693 \\
\hline BOD & $-0.0624^{* * *}$ & $-0.0547^{* * *}$ & $-0.0285^{*}$ & $-0.0285^{*}$ & 0.0101 & $-0.026^{*} 5$ & 0.0230 \\
\hline UE & $0.0507^{* * *}$ & 0.0410 & 0.0250 & 0.0250 & 0.0118 & 0.0238 & -0.0036 \\
\hline CFS & $-0.0434^{* * *}$ & $-0.0500^{* * *}$ & $0.0511^{* * *}$ & $0.0511^{* * *}$ & -0.0046 & $0.0598^{* * *}$ & $0.070^{* * *} 2$ \\
\hline AGE & -0.0179 & 0.0035 & $-0.0901^{* * *}$ & $-0.0901^{* * *}$ & $-0.0757^{* * *}$ & $-0.0771^{* * *}$ & -0.0105 \\
\hline & SIZE & BIG & LEV & BOD & UE & CFS & AGE \\
\hline SIZE & 1.0000 & & & & & & \\
\hline BIG & $0.3460^{* * *}$ & 1.0000 & & & & & \\
\hline LEV & $0.1611^{* * *}$ & $0.0385^{* *}$ & 1.0000 & & & & \\
\hline BOD & $0.1874^{* * *}$ & $0.1019^{* * *}$ & 0.0007 & 1.0000 & & & \\
\hline UE & -0.0060 & 0.0072 & $-0.0290^{*}$ & 0.0136 & 1.0000 & & \\
\hline CFS & $0.3191^{* * *}$ & $0.1045^{* * *}$ & $0.0344^{* *}$ & 0.0189 & $0.0263^{*}$ & 1.0000 & \\
\hline $\mathrm{AGE}$ & $0.1605^{* * *}$ & -0.0002 & 0.0193 & $0.0306^{*}$ & 0.0026 & $0.0869^{* * *}$ & 1.0000 \\
\hline
\end{tabular}

$*, * *, * *$ significant at $10 \%, 5 \%$, and $1 \%$ levels, respectively.

Please refer to the note of Table 2 for the definitions of the variables.

\subsection{Regression Analysis}

Our regression results of equation (1) are in Table 4. Panel A of Table 4 provides the results by measuring investors' heterogeneous beliefs with daily average trading volume (TV) and Panel B provides result by measuring investors' heterogeneous beliefs with daily abnormal trading volume (ATV). Panel A and Panel B's model 1 and model 2 are the results of matching level measurements by MAT and GMAT, and model 3 and model 4 are the results of matching level measurements by DMAT and PMAT.

In Panel A and Panel B of Table 4, the regression coefficient of matching level measurements (MAT, GMAT, DMAT and PMAT) are significantly negative value for all four models. This is consistent with the hypothesis, and this can be explained as matching level increases, investors' heterogeneous beliefs decrease.

As a result of the control variables, regression coefficient of voluntary announcement degree (VD) showed a significantly $(\mathrm{p}<1 \%)$ negative values in each model. This can be interpreted as quantity of information increases, so does trading volume. Regression coefficient of firm size (SIZE) showed significantly $((p<1 \%))$ negative value in each model. It mean that as firm size increases the level of information asymmetry decreases, thus investors' heterogeneous beliefs decrease as result. Regression coefficient of auditor Size (BIG) showed significantly $(\mathrm{p}<1 \%$ ) negative values in each model. These results mean that high audit quality can be a factor to reduce the trading volume. Regression coefficient of debt ratio showed significantly $(\mathrm{p}<1 \%)$ positive values in each model. Therefore, the risk of financial statement and bankruptcy can be explained as increasing investors' heterogeneous beliefs. Regression coefficient of excess outside director ratio (BOD) is significantly negative in each model. We did not expect the direction of sign on the regression coefficient of BOD. However, outside director policy is considered to contribute to lower investors' heterogeneous beliefs. The regression coefficient of unexpected earnings have significantly positive value. This is consistent with the study result of Choi and Shin (1997), thus it can be explained that unexpected earnings can cause various explanations for investors. Regression coefficient of firm age showed positive value only in model 3 of Panel A and Panel B. Although this is consistent with the result from Kwon and Moon (2012), it suggests that firm age can increase trading volume in a limited way. However, regression coefficient of consolidated financial statement (CFS) is shown to have no significance in each model. 
To summarize the results of Table 4, as matching level increases, trading volume decreases. This implies that as matching level increases, earnings quality increases, thus investors' heterogeneous beliefs decrease.

Table 4. Results of regression: the effect of matching level on investors' heterogeneous beliefs

\begin{tabular}{|c|c|c|c|c|c|c|c|c|}
\hline \multicolumn{9}{|c|}{$\begin{array}{l}T V(A T V)_{i, t}=\beta_{0}+\beta_{1} M A T C H_{i, t}+\beta_{2} V D_{i, t}+\beta_{3} S I Z E_{i, t}+\beta_{4} B I G_{i, t}+\beta_{5} L \\
+\beta_{11} I C O D E_{i, t}+\varepsilon_{i, t}\end{array}$} \\
\hline \multicolumn{9}{|c|}{ Panel A: Dependent variable is daily average trade volume(TV) } \\
\hline+2 & \multicolumn{2}{|c|}{$\begin{array}{c}\text { Model } 1 \\
\text { (MATCH= MAT) }\end{array}$} & \multicolumn{2}{|c|}{$\begin{array}{c}\text { Model 2 } \\
\text { (MATCH= GMAT) }\end{array}$} & \multicolumn{2}{|c|}{$\begin{array}{c}\text { Model 3 } \\
\text { (MATCH= DMAT) }\end{array}$} & \multicolumn{2}{|c|}{$\begin{array}{c}\text { Model } 4 \\
\text { (MATCH= PMAT) }\end{array}$} \\
\hline & Coef. & t-value & Coef. & t-value & Coef. & t-value & Coef. & t-value \\
\hline Intercept & 0.1126 & $14.83^{* * *}$ & 0.1116 & $14.84^{* * *}$ & 0.1079 & $14.27^{* * *}$ & 0.1144 & $14.96^{* * *}$ \\
\hline MAT & -0.0089 & $-5.59^{* * *}$ & & & & & & \\
\hline GMAT & & & -0.0096 & $-7.38^{* * *}$ & & & & \\
\hline DMAT & & & & & -0.0023 & $-2.47^{* *}$ & & \\
\hline PMAT & & & & & & & -0.0102 & $-5.58^{* * *}$ \\
\hline VD & 0.0161 & $4.74^{* * *}$ & 0.0153 & $4.51^{* * *}$ & 0.0171 & $5.02^{* * *}$ & 0.0161 & $4.72^{* * *}$ \\
\hline SIZE & -0.0029 & $-10.47^{* * *}$ & -0.0028 & $-10.11^{* * *}$ & -0.0030 & $-10.74^{* * *}$ & -0.0029 & $-10.52^{* * *}$ \\
\hline BIG & -0.0032 & $-4.42^{* * *}$ & -0.0032 & $-4.50^{* * *}$ & -0.0032 & $-4.41^{* * *}$ & -0.0032 & $-4.43^{* * *}$ \\
\hline LEV & 0.0202 & $11.42^{* * *}$ & 0.0196 & $11.07^{* * *}$ & 0.0209 & $11.76^{* * *}$ & 0.0201 & $11.31^{* * *}$ \\
\hline BOD & -0.0055 & $-1.98^{* *}$ & -0.0053 & $-1.91^{*}$ & -0.0048 & $-1.74^{*}$ & -0.0054 & $-1.95^{*}$ \\
\hline UE & 0.0021 & $3.54^{* * *}$ & 0.0020 & $3.44^{* * *}$ & 0.0020 & $3.42^{* * *}$ & 0.0021 & $3.53^{* * *}$ \\
\hline CFS & 0.0004 & 0.52 & 0.0006 & 0.79 & 0.0002 & 0.27 & 0.0005 & 0.57 \\
\hline AGE & 0.0007 & 1.46 & 0.0004 & 0.92 & 0.0009 & $1.93^{*}$ & 0.0007 & 1.58 \\
\hline YD & \multicolumn{8}{|c|}{ Included } \\
\hline ICODE & \multicolumn{8}{|c|}{ Included } \\
\hline F-vlaue & \multicolumn{2}{|c|}{$12.62^{* * *}$} & \multicolumn{2}{|c|}{$13.05^{* * *}$} & \multicolumn{2}{|c|}{$12.15^{* * *}$} & \multicolumn{2}{|c|}{$12.62^{* * *}$} \\
\hline $\operatorname{Adj} . \mathrm{R}^{2}$ & \multicolumn{2}{|c|}{0.1538} & \multicolumn{2}{|c|}{0.1586} & \multicolumn{2}{|c|}{0.1485} & \multicolumn{2}{|c|}{0.1537} \\
\hline
\end{tabular}

Panel B: Dependent variable is daily abnormal trade volume (ATV)

\begin{tabular}{|c|c|c|c|c|c|c|c|c|}
\hline & \multicolumn{2}{|c|}{$\begin{array}{c}\text { model } 1 \\
(\text { MATCH= MAT) }\end{array}$} & \multicolumn{2}{|c|}{$\begin{array}{c}\text { model } 2 \\
\text { (MATCH= GMAT) }\end{array}$} & \multicolumn{2}{|c|}{$\begin{array}{c}\text { model } 3 \\
\text { (MATCH= DMAT) }\end{array}$} & \multicolumn{2}{|c|}{$\begin{array}{c}\text { model } 4 \\
(\text { MATCH }=\text { PMAT) }\end{array}$} \\
\hline & Coef. & t-value & Coef. & t-value & Coef. & t-value & Coef. & t-value \\
\hline Intercept & 0.0672 & $9.85^{* * *}$ & 0.0662 & $9.80^{* * *}$ & 0.0625 & $9.19^{* * *}$ & 0.0691 & $10.05^{* * *}$ \\
\hline MAT & -0.0093 & $-6.45^{* * *}$ & & & & & & \\
\hline GMAT & & & -0.0099 & $-8.52^{* * *}$ & & & & \\
\hline DMAT & & & & & -0.0027 & $-3.12^{* * *}$ & & \\
\hline PMAT & & & & & & & -0.0107 & $-6.48^{* * *}$ \\
\hline VD & 0.0146 & $4.78^{* * *}$ & 0.0138 & $4.51^{* * *}$ & 0.0156 & $5.09^{* * *}$ & 0.0146 & $4.76^{* * *}$ \\
\hline SIZE & -0.0029 & $-11.54^{* * *}$ & -0.0028 & $-11.14^{* * *}$ & -0.0030 & $-11.84^{* * *}$ & -0.0029 & $-11.60^{* * *}$ \\
\hline BIG & -0.0031 & $-4.82^{* * *}$ & -0.0032 & $-4.92^{* * *}$ & -0.0031 & $-4.82^{* * *}$ & -0.0031 & $-4.83^{* * *}$ \\
\hline LEV & 0.0195 & $12.25^{* * *}$ & 0.0189 & $11.87^{* * *}$ & 0.0202 & $12.65^{* * *}$ & 0.0193 & $12.13^{* * *}$ \\
\hline BOD & -0.0049 & $-1.97^{* *}$ & -0.0047 & $-1.90^{*}$ & -0.0042 & $-1.70^{*}$ & -0.0048 & $-1.94^{*}$ \\
\hline UE & 0.0017 & $3.21^{* * *}$ & 0.0016 & $3.09^{* * *}$ & 0.0016 & $3.07^{* * *}$ & 0.0017 & $3.20^{* * *}$ \\
\hline CFS & 0.0005 & 0.68 & 0.0007 & 0.99 & 0.0003 & 0.40 & 0.0005 & 0.74 \\
\hline AGE & 0.0006 & 1.47 & 0.0004 & 0.84 & 0.0008 & $1.98^{* *}$ & 0.0007 & 1.60 \\
\hline YD & \multicolumn{8}{|c|}{ Included } \\
\hline ICODE & \multicolumn{8}{|c|}{ Included } \\
\hline F-vlaue & \multicolumn{2}{|c|}{$7.91^{* * *}$} & \multicolumn{2}{|c|}{$8.45^{* * *}$} & \multicolumn{2}{|c|}{$7.36^{* * *}$} & \multicolumn{2}{|c|}{$7.92^{* * *}$} \\
\hline Adj. $R^{2}$ & \multicolumn{2}{|c|}{0.0975} & \multicolumn{2}{|c|}{0.1044} & \multicolumn{2}{|c|}{0.0904} & \multicolumn{2}{|c|}{0.0976} \\
\hline
\end{tabular}




\subsection{Additional Analysis}

According to the literature, the regression coefficient of equation (6) $\beta_{2}$ is shown to have relation with current revenue and current expense (Dichev \& Tang, 2008; Paek, 2011a; Jung \& Lee, 2014). They explained that, as the value of $\beta_{2}$ increases, correlation of current profit and current expense increases, thus the regression coefficient of $\beta_{2}$ shows a matching level.

However, they submitted equation (6) to OLS regression analysis. As mentioned above, if equation (6) is analyzed through OLS regression, the first autocorrelation problem can occur. So this study re-tested the hypothesis by considering each firm's calculated $\beta_{2}$ as matching level's proxy after analyzing equation (6) by Prais-Winsten estimation method.

As a result of analysis of equation (6) by Prais-Winsten estimation method, $\beta_{2}$ average(median) of equation (6) was shown as 1.0107(1.0215) and the standard deviation was 0.2987. Paek (2011a) reports the average and the median as 0.987 and 1.021 , and the standard deviation was reported as $0.274 .^{2}$

Table 5 is the additionally analyzed result on the impact that matching level has on investors' heterogeneous beliefs after measuring equation (6) $\beta_{2}$ (PEXP2) by Prais-Winsten estimation method. Model 1 is the result of setting daily average trading volume (TV) as dependent variable, and model 2 is the result of setting Daily abnormal trading volume (ATV) as dependent variable. According to the analysis results, regression coefficient on PEXP2 is significantly negative at the $1 \%$ level in both model 1 and model 2 . This is consistent with the result from Table 4 , and it suggests that as matching level improves, investors' heterogeneous beliefs decrease.

Table 5. Additional Test: the effect of matching level ( $\beta_{2}$ measured based on Prais-Winsten methods) on investors' heterogeneous beliefs

\begin{tabular}{|c|c|c|c|c|}
\hline \multicolumn{5}{|c|}{$T V(A T V)_{i, t}=\beta_{0}+\beta_{1} P E X P 2_{i, t}+\beta_{2} V D_{i, t}+\beta_{3} S I Z E_{i, t}+\beta_{4} B I G_{i, t}+\beta_{5} L E V_{i, t}+\beta_{6} B O D_{i, t}+\beta_{7} U E_{i, t}+\beta_{8} C F_{i, t}+\beta_{9} A G E_{i, t}+\beta_{10} Y D_{i, t}$} \\
\hline & \multicolumn{2}{|c|}{ model 1(TV) } & \multicolumn{2}{|c|}{ model $2(\mathrm{ATV})$} \\
\hline & Coef. & t-value & Coef. & t-value \\
\hline Intercept & 0.1109 & $14.61^{* * *}$ & 0.0649 & $9.51^{* * *}$ \\
\hline PEXP2 & -0.0048 & $-4.49^{* * *}$ & -0.0046 & $-4.73^{* * *}$ \\
\hline VD & 0.0170 & $5.00^{* * *}$ & 0.0155 & $5.08^{* * *}$ \\
\hline SIZE & -0.0030 & $-10.63^{* * *}$ & -0.0029 & $-11.73^{* * *}$ \\
\hline BIG & -0.0031 & $-4.29^{* * *}$ & -0.0030 & $-4.67^{* * *}$ \\
\hline LEV & 0.0200 & $11.25^{* * *}$ & 0.0194 & $12.10^{* * *}$ \\
\hline BOD & -0.0050 & $-1.80^{*}$ & -0.0044 & $-1.76^{*}$ \\
\hline UE & 0.0020 & $3.30^{* * *}$ & 0.0016 & $2.94^{* * *}$ \\
\hline CFS & 0.0003 & 0.34 & 0.0003 & 0.46 \\
\hline $\mathrm{AGE}$ & 0.0008 & $1.80^{*}$ & 0.0008 & $1.89^{*}$ \\
\hline YD & \multicolumn{4}{|c|}{ Included } \\
\hline ICODE & \multicolumn{4}{|c|}{ Included } \\
\hline F-vlaue & \multicolumn{2}{|c|}{$12.42^{* * *}$} & \multicolumn{2}{|c|}{$7.58^{* * *}$} \\
\hline Adj. $\mathrm{R}^{2}$ & \multicolumn{2}{|c|}{0.1515} & \multicolumn{2}{|c|}{0.0932} \\
\hline
\end{tabular}

*Two-tailed t-tests, ${ }^{*}, * *, * * *$ significant at $10 \%, 5 \%$, and $1 \%$ levels, respectively.

Please refer to the note of Table 2 for the definitions of the variables except for the following. PEXP2 is $\beta_{2}$ of equation (6) measured by using

Prais - Winsten methods. YD is a dummy variable for year. ICODE is a dummy variable for industry.

\footnotetext{
${ }^{2}$ It is inappropriate to compare equation (6) $\beta_{2}$ value that was calculated by Prais-Winsten estimation method directly with $\beta_{2}$ value that is being reported by Paek (2011a), but $\beta_{2}$ that was measured by Prais-Winsten estimation method and the measured value through OLS regression analysis look to have similar dispersion with each other.
} 


\section{CONCLUSION}

This study analyzed the hypothesis that matching level and investors' heterogeneous beliefs will have negative relation. Investors' heterogeneous beliefs that were used in analysis were measured by trading volume, and trading volume was measured by the methodology of Morse (1981), Beaver (1968), Bamber (1987) and Ziebart (1990).

The literature on trading volume argued that the trading volume increases when investors' heterogeneous beliefs regarding intrinsic value of the firm is different. Therefore, they reported that, as unexpected earnings increase, so does trading volume, but as earnings quality, information asymmetry and information environment improve, trading volume decreases.

The literature on matching level has explored the impact that improvement of matching level has on earnings quality, accumulated market adjusted return, foreign ownership, future earning response coefficient (FERC) and bond credit rating. However, they disregarded the problem of measuring matching level. This study has therefore suggested an additional proxy of matching level besides the proxy of matching level suggested by the literature.

This study has used the calculated explanatory power $\left(\right.$ Adj. $\left.R^{2}\right)$ as an additional proxy of matching level after analyzing the model of Paek (2011b) by Prais-Winsten estimation methodology. This can solve the problem of the first autocorrelation. We have conducted an analysis on how matching level affects investors' heterogeneous beliefs by using the matching level measurement from the literature on matching level and the matching level measurement suggested by this study.

To empirically analyze the hypothesis of this study, we used firm-year observation from 4,094 firms listed on Korean Stock Exchange over the period from 2003 to 2011. We found that matching level regression coefficient consistently showed significantly negative values for each measurement. Moreover, we also measured the calculated regression coefficient $\left(\beta_{2}\right)$ of current expenses as matching level response coefficient after analyzing Dichev and Tang's (2008) matching level measuring model by Prais-Winsten estimation method. It showed that regression coefficient of the current expenses and trading volume have a negative correlation. This is consistent with this study, and it shows that as matching level improves, investors' heterogeneous beliefs decrease.

According to the microeconomics theory of Mas-Colell et al., (1995), trading volume can affect price changes. However, accounting studies analyze the information effect by using price change only. Therefore, this study is meaningful in that it conducted an analysis on the information effect of matching level through trading volume. This study is also expected to improve our understanding of the microscopic structure of the capital market.

\section{AUTHOR BIOGRAPHIES}

Hyunuk Jung, Ph. D., is an Assistant Professor of Accounting at Dong-A University, South Korea. He holds a Ph.D. in Management (Accounting Concentration) from Yeungnam University, South Korea (the first author).

Sanghyuk Moon, Ph. D., is an Associate Professor of School of Business at Yeungnam University, South Korea. He holds a Ph.D. in Management (Accounting Concentration) from Sungkyunkwan University, South Korea. Email: shmoon@ynu.ac.kr (corresponding author).

\section{REFERENCES}

Ajinkya, B.B., Atiase, R. K., \& Gift, M. J. (1991). Volume of trading and the dispersion in financial analysts' earnings forecasts. The Accounting Review, 66(2), 389-401.

Ashbaugh-Skaife, H., Collins, D. W., \& LaFond. R. (2006). The effects of corporate governance on firms' credit ratings. Journal of Accounting and Economics, 42(1-2), 203-243.

Bamber, L. S. (1987). Unexpected earnings, firm size, and trading volume around quarterly earnings announcements. The Accounting Review, 62(3), 510-532.

Beaver. W., (1968). The information content of annual earnings aAnnouncements. Journal of Accounting Research, 6, 67-92.

Becker, C. L., DeFond, M. L., Jiambalvo, J. \& Subramanyam, K. R. (1998). The effect of audit quality on earnings management. Contemporary Accounting Research, 15(1), 1-24. 
Bhattacharya, N., Ecker, F., Olsson, P. \& Schipper, K. (2012). Direct and mediated associations among earnings quality, information asymmetry, and the cost of equity. The Accounting Review, 87, 449-482.

Bhushan, R. (1989). Firm characteristics and analyst following. Journal of Accounting and Economics 11(2/3), $255-274$.

Choen, Y. S. (2003). The association between foreign and domestic institutional ownership and earnings quality. Korean Management Review, 32(4), 1001-1032. [Printed in Korean]

Choi, J. S., \& Shin, S. M. (1997). The effect of trading volume on earnings announcement. Korean Accounting Review, 22(1), 136. [Printed in Korean]

Choi, K. H., \& Yoon, S. M. (2012). The effect of trading volume on asymmetry and persistence of returns volatility in the Korean Stock Market. Journal of Industrial Economics and Business, 25(2), 1729-1750. [Printed in Korean]

Diamond, D., \& Verrecchia, R. (1991). Disclosure, liquidity, and the cost of capital. Journal of Finance, 46(4), $1325-1360$.

Dichev, I. \& Tang. V. (2008). Matching and the changing properties of accounting earnings over the last 40 years. The Accounting Review, 83, 1425-1460.

Dormeier, B. P. (2011). Investing with volume analysis: Identify, follow, and profit from trends. FT Press.

Francis, J., Lafond, R., Olsson, P., \& Schipper, K. (2004). Cost of equity and earnings attributes. The Accounting Review, 79(4), 967-1010.

Gujarati, D. (2011). Econometrics by Example. Palgrave Macmillan.

Han, B. H. (2001). The measurement of unexpected earnings and abnormal stock returns. Asia-Pacific Journal of Financial Studies, 29(1), 1-47. [printed in Korean]

Haw, I. M., Hu, B., \& Lee, J. J. (2012). Investor protection and price informativeness about future earnings, international evidence. Review of Accounting Studies, 17(2), 389-419.

Hwang, I. T. (1995). Usefulness of consolidated financial statements. Korean Accounting Review, 20(2), 59-75. [Printed in Korean]

Jung, H. U., \& Lee, K. I. (2014). The effect of the matching level on audit hours. Journal of Taxation and Accounting, 15(4), 113-149. [Printed in Korean]

Jung, H. Y. (1990). The effect of commonality between trading volume fluctuations and rate of return dispersion in the point of earnings disclosures. Korean Accounting Review, 10(1), 133-150. [Printed in Korean]

Karpoff. J. M. (1986). A theory of trading volume. The Journal of Finance, 41 (5), 1069-1087.

Kim, C. S. (2006). Outside directors and firm value in Korea. Asian Review of Financial Research, 19(2), 105-153. printed in Korean]

Kim, M. T., \& Kim, Y. H. (2007). The impacts of foreign ownership and outside directors on bond grading. Korean Accounting Review, 32(4), 29-58. [Printed in Korean]

Kim, O., \& Verrecchia, R. (1994). Market liquidity and volume around earnings announcements. Journal of Accounting and Economics, 17(1-2), 41-67.

Ko, D. Y., Baik, E. Y., \& Ahn, M. K. (2012). The effect of corporate governance on foreign investor ownership. Accounting Information Review, 30 (1), 29-59. [Printed in Korean]

Kwon, S. Y., \& Ki, E. S. (2011). The effect of accruals quality on audit hours and audit fees. Korean Accounting Review, 36(4), 95-137. [Printed in Korean]

Kwon, S. Y., \& Moon, B. Y. (2012). The effect of corporate life cycle on audit hours and audit fees. Study on Accounting, Taxation \& Auditing, 54(1), 105-146. [Printed in Korean]

Lee, H. J., \& Jung, H. U. (2014). The matching level and information effect of future earnings. Study on Accounting, Taxation \& Auditing, 56(2), 9-47. [Printed in Korean]

Lee, K. I. (2014). The effect of matching level on foreign equity ownership. Korea International Accounting Review, 54, 152179. [Printed in Korean]

Lee, S. S., Goh, J. M., Cho, J. E., \& Choi. S. Y. (2013). Matching principle and analysts' herding behavior in forecasting. Korean Academic Society of Accounting, 18(2), 209-251. [Printed in Korean]

Mas-Collel, A., Whinston, M. D., \& Green, J. R. (1995). Microeconomic theory. New York. Oxford University Press.

Morse. D. (1981). Price and trading volume reaction surrounding earnings announcements: A closer examination. Journal of Accounting Research, 19(2), 374-383.

Paek, W. S. (2011a). Fair-value accounting, historical principle, matching principle. Korean Business Review, 40(1), 57-77. [Printed in Korean]

Paek, W. S. (2011b). The matching principle and earnings quality. Korean Accounting Review, 36(2), 101-127. [Printed in Korean]

Prais, S., \& Winsten, C. (1954). Trend estimation and serial correlation. Discussion Paper 383. Cowles Commission, Chicago, IL.

Roh, B. G., \& Lee, S. Y. (2012). Revenue-expense matching and market reaction to accounting information. Korean Accounting Review, 37(3), 345-375. [Printed in Korean]

Roh, B. G. (2013). A study on the matching revenue-expense and analysts' forecast accuracy. Korean Accounting Journal, 21(6), 59-95. [Printed in Korean]

Sohn, S. K., Jin, K. B., \& Hua, J. L. (2008). The effect of voluntary disclosures on analysts' earnings forecasts. Accounting Information Review, 26(2), 1-26. [Printed in Korean] 
Sohn, S. K., Ko, J. M., \& Paik, H. W. (2009). The information content of accruals quality. Accounting Information Review, 27(2), 273-304. [Printed in Korean]

Tucker, J. W., \& Zarowin, P. A. (2006). Does income smoothing improve earnings informativeness. The Accounting Review, 81(1), 251-270.

Yang, D. C., \& Seo, Y. H. (2014). Revenue-expense matching and corporate bond ratings. Korean Business Education Review, 29(6), 330-353. [Printed in Korean]

Ziebart, D. A. (1990). The association between consensus of beliefs and trading activity surrounding earnings announcements. The Accounting Review, 65(2), 477-488. 
NOTES 